\title{
Explaining the density of post-communist interest group populations-resources, constituencies, and regime change
}

\author{
Rafael Labanino $^{1}$ D $\cdot$ Michael Dobbins ${ }^{1} \cdot$ Brigitte Horváthová $^{1}$
}

Accepted: 16 July 2021 / Published online: 26 July 2021

(C) The Author(s) 2021

\begin{abstract}
The article tests the energy-stability-area (ESA) model of interest group population density on a sample of different 2018 Czech, Hungarian, Polish and Slovenian energy, higher education and health care interest organisation populations. The unique context of recent simultaneous political, economic and in the cases of Czechia and Slovenia, national transitions present a hard test for population ecology theory. Besides the area (constituency size) and energy (resources, issue certainty) terms, the article brings the stability term back into the center of analysis. The stability term, that is, the effect of a profound change or shock to the polity is operationalised as Communist-era population densities. As all three policy domains are heavily state controlled and tightly regulated, the effect of neocorporatist interest intermediation is also tested. The article finds strong support for the energy and neocorporatism hypotheses and provides evidence for the effect of communist-era organisational population density on post-transition densities: The size of 2018 organisational populations is found to be dependent on pre-transition densities. The relationship is, however, not linear but curvilinear. Nevertheless, the analysis indicates that the effect of pre-transition population size is moderated by other environmental level factors.
\end{abstract}

Keywords ESA model - Central and Eastern Europe · Post-communist transition · Corporatism - Party system closure

Rafael Labanino

rafael.labanino@uni-konstanz.de

Michael Dobbins

michael.dobbins@uni-konstanz.de

Brigitte Horváthová

brigitte.horvathova@uni-konstanz.de

1 Department of Politics and Public Administration, University of Konstanz, Universitätsstraße 10, 78457 Konstanz, Germany 


\section{Introduction}

The density and variation of interest organisations across public and business sectors are not only of theoretical but also great political and societal importance. Density was shown to affect the strategies, influence and the level of policy engagement of interest groups (Beyers and Kerremans 2007; Lowery et al. 2008; Halpin and Thomas 2012). Density is also one of the most important population-level factors affecting the vital rates - that is the formation, entry and mortality-of interest groups (Gray and Lowery 1996a; Hannan and Carroll 1992; Hannan and Freeman 1989, 1977; Nownes and Lipinski 2005; Nownes 2004). According to Olson (1982), high interest group density is harmful for economic sectors, because as their numbers grow (which he assumed to be exponential), interest groups increasingly represent narrow, special interests, which lobby against policy change and engage in rent-seeking. Other scholars, however, find interest groups essential for interest representation and democratic decision-making (Fraussen and Halpin 2018; Klüver 2015) as party politics becomes ever more detached from the electorate (Biezen and Poguntke, 2014; Mair 2013). Until recently, the diversity and density of interest and lobby group populations were studied mostly on the sample of US states (e.g., Bevan 2013; Gray and Lowery 1995, 1996a; Lowery and Gray 1995; Minkoff et al. 2014). However, lately, numerous studies were published on European Union (EU)-level populations (e.g., Berkhout et al. 2015, 2018; Berkhout and Lowery 2011; Wonka et al. 2010) and different aspects (diversity, access to policy-makers) of nationallevel interest group populations in Europe and elsewhere (Binderkrantz et al. 2015; Fraussen and Halpin 2016; Fraussen et al. 2015; Lizzi and Pritoni 2017).

This research agenda is, however, almost entirely missing in the post-communist context, which is surprising for a number of reasons. First, the simultaneous political and economic transition from totalitarian party states and command economies to democratic capitalism, which in many cases also involved newly (re)gained national sovereignty (Offe 1991), is a unique historical experience. Moreover, seminal social science studies argue that the density and variance of civil society organisations are key factors explaining democratisation and economic growth in general (Olson 1965, 1982; Putnam et al. 1994). Influential studies on the post-communist policy reform process stressed the importance of special interests in blocking the consolidation of democratic capitalism (Hellman 1998) and hindering the adoption of neoliberal social and economic reforms (Gehlbach and Malesky 2010). Although many studies have been devoted to civil society mobilisation and industrial relations (unions, employer's organisations, state-labor relations) in Central and Eastern Europe (CEE) (e.g., Avdagic 2005; Bruszt et al. 2010; Crowley and Ost 2001; Ekiert and Kubik 1998; Kopecký and Mudde 2003; Krzywdzinski 2008; Greskovits 1998; Ost 2005), interest groups and lobbying in general are understudied in the postcommunist context. With some notable exceptions (Armingeon 2011; Fink-Hafner 1997, 2011; Gallai et al. 2015; Hanley 2013; Novak and Fink-Hafner 2019; Pleines 2004), the number and diversity of interest organisations, and their influence, their role in policy-making, their access to the different lobbying arenas or the media have mostly yet to be addressed by scholars. 
The number, evolution and composition of the interest organisation landscape were recently explored by Sebestény (2017) in the Hungarian and by Rozbicka and Kamiński (2021) in the Polish context. Earlier, Fink-Hafner (1997) provided data and analysis of the number and diversity of Slovenian interest groups before and after the political and economic transition. However, theoretically driven comparative studies on a sample of interest group populations in different public and business sector domains across several CEE countries were only recently published (Dobbins et al. 2021; Labanino et al. 2020, 2021). Although these articles test the theory of density dependence (Hannan and Carroll 1992) and political opportunity structure (Meyer and Minkoff 2004; Meyer and Imig 1993) to explain the vital rates of CEE interest group populations, none of them addresses the factors defining interest group population density. Rather, density is treated as an explanatory variable. We aim to fulfill this research gap by testing which factors explain the variance in the densities of a sample of Czech, Hungarian, Polish and Slovenian higher education, health care and energy policy interest group populations. Thus, we conceive density as a dependent variable.

The post-communist context offers exciting and challenging opportunities. For example, while there is a varying share of communist-era organisations in contemporary interest group populations across countries and policy domains, the economic, political and national transitions together with the EU accession process represent profound changes for these countries. Against this background, the article continues as follows. In the next section, we introduce the energy-stability-area (ESA) model of interest group population density (Gray and Lowery 1996c) and the third section adapts the ESA model to the post-communist context, sets up the theoretical framework and states the hypotheses. The fourth section describes the case selection and operationalises the dependent and independent variables, while the fifth section describes the applied statistical model and provides the analyses. In the last section, we discuss our results and suggest areas for future research.

\section{The population ecology approach and the ESA model of interest group population density}

Population ecology studies the success and failure, or in population ecology terms, the reasons behind the founding and mortality of organisations on the aggregate level. Ever since Stinchcombe's (1965) seminal essay on organisations, demographic processes, such as the liability of newness or the liability of aging among others, have been in the focus of sociological research (Baum and Amburgey 2002). However, it was first Hannan and Freeman (1977) who dealt with organisations explicitly in human ecology terms by defining populations as aggregates of organisations that were 'relatively homogenous in terms of environmental vulnerability' (934). In other words, organisational selection happens at the level of populations and not at the level of individual organisations. The vital rates of organisations, that is, formation and failure are assumed to be density dependent (Hannan and Carroll 1992).

The ESA model is an application of population ecology theory to the determinants of the size of interest organisation populations first suggested and tested by 
Lowery and Gray (1995). According to the model, organisational diversity and density are determined by the carrying capacity of the organisations' environment and not by organisation-level variables. The model posits that 'the diversity of a population is a summed function of how the environmental forces specified in the ESA model separately influence carrying capacities for each species or organisation type' (Gray and Lowery 1996a, p. 105). These environmental constraints are the number of potential constituents, constituent interest and issue certainty. The number of potential constituents corresponds to the area term of the model, the "habitat" or size of population of the interest organisation constituency. In many studies, habitat is labeled simply as the supply side (population/membership environment). The other two variables correspond to energy_-or the demand side - in the model: Constituent interests are the current and potential government actions of direct concern of interest, and issue certainty is the likelihood of policy change, which are the 'vital resources that interest organisation entrepreneurs employ to secure sponsorship' (Gray and Lowery 1996a, p. 106). As Berkhout et al. (2015) summarises, the underlying theoretical assumption of the population ecology approach is that the number of organisations is constrained by 'the availability of organisational resources, relatively independent of mobilisation rates and dependent on the pre-existing density of organisations' (2015, p. 465). The stability term refers to profound changes, disruptions to the political system, such as a totalitarian rule or foreign occupation, as also argued by Olson (1982). The stability term, however, is usually not operationalised and tested in the literature.

\section{Theoretical framework and hypotheses}

Two articles are of high importance in constructing a framework for the present study, Lowery and Gray (1995) on US state interest group densities and Berkhout et al. (2015) on the density of EU-level business lobby groups. Lowery and Gray (1995) test the ESA model on the density of interest groups in both public and business sector guilds at the US state level. In addition to the number of possible constituents, constituent interests and the size of government, they also operationalise and test the stability term with the age of the interest group system, which is important in the context of relatively recent post-communist transitions. Issue certainty is measured by the intensity of party competition as a crucial energy/demand-side factor.

Berkhout et al. (2015) apply the ESA model to explain interest group density in the European Parliament per economic sector. Besides the number of constituents in a sector, Berkhout et al. (2015) test the area term with the wealth of the potential constituents, the level of EU market integration, the proportion of institutions, and the presence of an umbrella group (cue-giver hypothesis). The energy term is tested with EU policy activity (spending per DG, the total number of legislative acts) and the information needs of the administrations.

In general, Berkhout et al. (2015) find support for the supply-side factors, whereas the results for the demand-side factors-policy activity and information needs-are inconsistent. Lowery and Gray (1995) found that both issue uncertainty-that is, 
more intense political competition-and constituent interests affect organisational densities positively. However, the coefficients for government size and the stability term are neither in the expected direction nor significant.

\section{Exploring the stability term}

Our study draws on Lowery and Gray (1995) and Berkhout et al. (2015) but adjusts the model to the post-communist context. Our study brings the stability term back into the analysis. The stability term has been constant for the American states (Gray and Lowery 1996b) and fairly constant for Western Europe-as World War II and with it foreign occupation and totalitarian regimes are more than 70 years away. Following Olson (1982), the stability term was tested by Lowery and Gray (1995) with the age of interest systems, and just as expected by the authors, it did not bring any results. We operationalise the stability term differently: We consider the stability term as a part of the area-habitat—-term of the model. More precisely, we assume that the profound change to the polity, which the political (democratic) and economic (capitalist) transition represents, affects post-transition interest groups populations by constraining the carrying capacity of the political system but to a largely varying degree for different interest group populations.

According to Olson (1982), after a major disruption to the political system, such as a regime change or military occupation, interest group formation begins anew and continues exponentially until another major disruption. Olson cites from another study supporting his argument that while $51 \%$ of all associations existing in the UK in 1973 were founded before 1939, the corresponding numbers were much lower in countries experiencing totalitarianism and foreign occupation: 24\% in West Germany, 19\% in Japan and 37\% in France (Olson 1982, p. 173). However, Olson never addresses the question whether these proportions are as low as his theory would assume-more or less a tabula rasa - and what it could mean for the post-regime change interest group formation rates, diversity and density.

Exploring the dynamics and determinants of the variance in Czech, Hungarian, Polish and Slovenian health care, higher education and energy policy interest group formations in the communist era Labanino et al. (2021) found not only a sizable organisational density at the outset of transition (1990-1991) but also that these communist-era organisations were successful in the new, democratic regimes as well. Moreover, on the Hungarian subsample-where data on dissolutions were reliably available - the study found that these organisations have a much lower dissolution rate than those founded since 1990: On average, a mere $6.3 \%$ of pre-transition Hungarian higher education, health care and energy groups were dissolved by 2019 , compared with $27.8 \%$ among those founded since 1990 .

There is also evidence that communist-era organisations follow different advocacy strategies than organisations founded before or after communism. On the basis of a survey of Hungarian interest organisations, Gallai et al. (2015) found that formation during communism had a significant and positive effect on governmental and civil relations over pre-communist-era and post-communist-era 
organisations. That is, communist-era organisations might enjoy a significant advantage in access to policy-makers and in network relations to other groups.

Based on these studies, pre-transition densities might be one of the most important population-level factors explaining density in post-communist interest group populations. We assume that pre-transition population density is a part of the habitat, the area term. If they truly enjoy higher survival rates and are among the more influential interest groups despite the historic rupture of the double political-economic (and in case of Czechia and Slovenia an additional national) transition, their size should constrain the carrying capacity of the "environmental niche" of an interest group population substantially.

However, sizable pre-transition densities might also have induced higher initial formation rates. In the population ecology theory, the vital-foundation and mortality_rates of interest groups are assumed to be density dependent. Initially, as an organisational form gains legitimacy by a growing density, formations also increase and the number of failures decreases. However, at relatively high levels of density competition increases, which leads to lower formation and higher dissolution rates. The relationship between density and founding follows a $\cap$ shape, and the relationship between density and failure has a $U$ shape (Hannan and Carroll 1992). That is, a relatively large density at the time of the collapse of the communist regimes in a population may affect foundations positively as the organisational forms are already seen as legitimate.

Hypothesis 1 Pre-transition densities are in a positive relationship with contemporary densities.

However, a large pre-transition density might also set in a relatively early saturation, which would in turn cause lower foundation and higher mortality rates as competition intensifies. Moreover, from the assumed positive relationship, we simply would not know whether the positive effect is because of the lower mortality rate of communist-era organisations, the legitimacy process associated with relatively large densities, or because the size of pre-transition density simply signals large and well-organised latent constituencies and abundant governmental resources in the first place.

Based on the population ecology of vital rates, the relationship between pretransition densities and post-transition vital rates might be curvilinear. That is, relatively sizable pre-transition densities affect post-transition densities through higher formation and lower mortality rates up until a certain level positively (albeit, at a declining rate). However, based on the studies of the success of communist-era organisations-in survival, and in access to policy-makers and networking-in the democratic capitalist regimes, the 1989 population size might affect post-1989 population growth and contemporary density after a certain level negatively. In other words, relatively large pre-transition densities might lead to early saturation and/or communist-era organisations might simply crowd out post-transition organisations. 
Hypothesis 2 We expect the relationship between pre-transition and post-transition densities to be curvilinear.

\section{Exploring the energy and area terms}

For the supply-side/area term, we include the number of (latent) constituents.

Hypothesis 3 We expect a positive relationship_although at a declining rate (see Berkhout et al. 2015)—between constituency size and population density.

In the demand-side/energy term, we test the standard constituent interest hypothesis and issue certainty. The former is usually tested with the government resources relevant for an interest group population, and we follow this approach.

Hypothesis 4 We expect a positive relationship between government expenditures in an area and the number of interest groups active in that area.

Issue certainty is of particular theoretical interest in the post-communist context. According to Lowery and Gray (1995), the energy needed to support a group's constituency varies with the likelihood of policy change. If it is unlikely that government policy will be altered regarding essential resources for a group's constituency, there will be little incentive to lobby for or against policy change. The most general source of issue uncertainty is party competition: If control of government is highly competitive, the likelihood of significant policy change is also higher (Lowery and Gray 1995, p. 17). CEE party systems are characterised by high volatility and in general exhibit low levels of institutionalisation (Bértoa 2013; Bértoa and Mair 2012). There is a considerable regional variance though with Latvia and Poland being the least institutionalised, while Hungary, Romania and Slovenia have the region's most stable party systems (Bértoa and Enyedi 2016; Enyedi and Bértoa 2018). Moreover, CEE party systems oscillate between phases of volatility with high party foundations rates and phases of relative stability (Ibenskas and Sikk 2017). A sample of post-communist countries offers the possibility to test whether party competition in a high volatility environment is also a resource for interest organisations.

Hypothesis 5 We expect the level of party competition to affect density positively.

However, a different conceptualisation is necessary than the one Lowery and Gray (1995) used - the folded Ranney index — which was developed for the American political system (see below).

In addition to the ESA model, we also include the nature of the national interest intermediation system. In most of CEE some form of tripartite, corporatist interest intermediation institutions were put in place initially (Iankova 2002). However, there were great differences between these systems and labor suffered from structural weaknesses (Avdagic 2006; Crowley and Ost 2001). During the 
last decade, social dialog was weakened or abandoned entirely in several CEE countries (Korkut et al. 2017; Szabó 2013).

Hypothesis 6 Neocorporatist arrangements reduce interest group density.

Neocorporatism restricts the access of interest organisations to policy-makers, thus limiting the carrying capacity of the political-institutional environment for interest groups. Conversely, we expect more pluralist interest intermediation systems to affect organisational density positively.

\section{Case selection and data}

We selected a sample of Czech, Hungarian, Polish and Slovenian health care, higher education and energy policy organisations active on the national level to test our density model. The country selection controls for some important political, institutional and economic characteristics. Firstly, these countries all were part of the first EU accession round in 2004 (Vachudova 2005). Moreover, all of them boast a high value-added manufacturing export sector, enjoyed high FDI inflows and are characterised by comparatively high welfare spending (Bohle and Greskovits, 2012). However, they show a considerable variance on several factors of theoretical importance for the present study. Their party systems exhibited different levels of institutionalisation with the Hungarian and Slovenian being the most and the Polish the least institutionalised party systems of the four, while the Czech system occupies a middle position (it was quite stable for more than a decade followed by a period of increasing volatility). Their interest intermediation systems also vary. Slovenia is seen as the model Eastern European neocorporatist small state (Jahn 2016). Hungary had the most fragmented union landscape, whereas Poland had the most polarised and politicised one. Czechia has been closer to the classic neocorporatist model than either Hungary or Poland (Avdagic 2006; Bohle and Greskovits 2012). Nevertheless, union density decreased steadily in all four countries during the last two decades, and the Hungarian government abandoned the tripartite model of interest intermediation in 2011 (Szabó 2013; Tóth 2012).

The three selected policy areas-health care, higher education and energyare diverse and not interrelated, thus increasing the generalisability of the findings. Second, the issues represent a large portion of public budgets and are of long-term strategic importance for the well-being of nations. Third, all three policy areas have both a regulatory and redistributive component and can therefore be regarded as "internally heterogeneous," again increasing the generalisability of our findings. Fourth, the interest group landscape includes both concentrated interests (e.g., energy producers, health care providers/physicians, professoriate) and more diffuse interests (environmental groups, health care consumers, students) (see Olson 1965). Moreover, all include both public, non-state and business interest groups, albeit to a varying degree. 
We identified a total of 1345 active national-level interest organisations in 2018, and a total of 264 organisations active in 1989 across the three policy areas, 13 populations and four countries (Table 1). As a rule, we collected data from public registries of civil society organisations. We cross-checked the data with Internet searches, lists from parliaments and different ministries that invited organisations to various committees, meetings and interest intermediation bodies. We used the same set of keywords in all four languages. As in health care and higher education, there are highly specialised professional, patient and student groups, we also made a standardised list of medical professions and higher education disciplines to improve comparability. For Poland, we used the National Court Registry (Krajowy Rejestr Sadowy-KRS) as a starting point. Since the KRS database only indicates registrations from 2001 on, we checked for each organisation whether it was founded before this period, and systematically searched for organisations founded before 2001. Our main source for the Hungarian data was the Court Registry of Civil Society Organisations. The Hungarian court registry starts in 1989, that is, organisations founded before that date nonetheless have 1989 as their founding date. In each case though, we checked for the actual foundation date. For Slovenia, our primary source was the AJPES registry (Agency of the Republic of Slovenia for Public Legal Records and Related Services). Our main source for the Czech data was the registry of the Czech Statistical Office.

With the exception of Hungary, these registries do not contain information on dissolutions. Therefore, we systematically checked whether organisations were active or inactive with web searches and even by contacting them. In many cases, we could not determine the exact date of dissolution, only the last date of activity or that the organisation was active/inactive at the time of data collection (2019). The information on dissolutions in the Hungarian registry also has limitations. The unified court registry was established in 2011, and the courts started to dissolve inactive organisations effectively as of 2014. As a result, there has been a "mass dissolution" of organisations since then, even though most have been inactive for years if not decades (Sebestény 2017).

We coded the organisations in each policy domain to smaller populations to control for the environmental pressures these organisations face at the aggregate level. Energy interest groups are divided into fossil, nuclear, renewable (both sectional and business groups in these latter populations) and environmental protection interest organisation populations (we added only environmental groups that deal with clean energy and/or air pollution issues). Higher education organisations are grouped based on whether they represent general higher education faculty/employee interests (labor), student interests, institutional interests (e.g., Rector's conferences) or the interests of specific, scientific communities (e.g., political science associations). Health care groups were sorted into five populations: business (e.g., pharmaceutical), institutional (e.g., hospitals), non-medical staff, medical doctors and medical professional, and patient interest group populations. That is, we distinguished between 13 populations across three policy domains. Thus, our sample comprises a total of 52 national-level interest group populations in the four countries.

Table 1 provides a breakdown of our organisational populations. It shows that the 1989 populations were characterised by a considerable variance across the four 


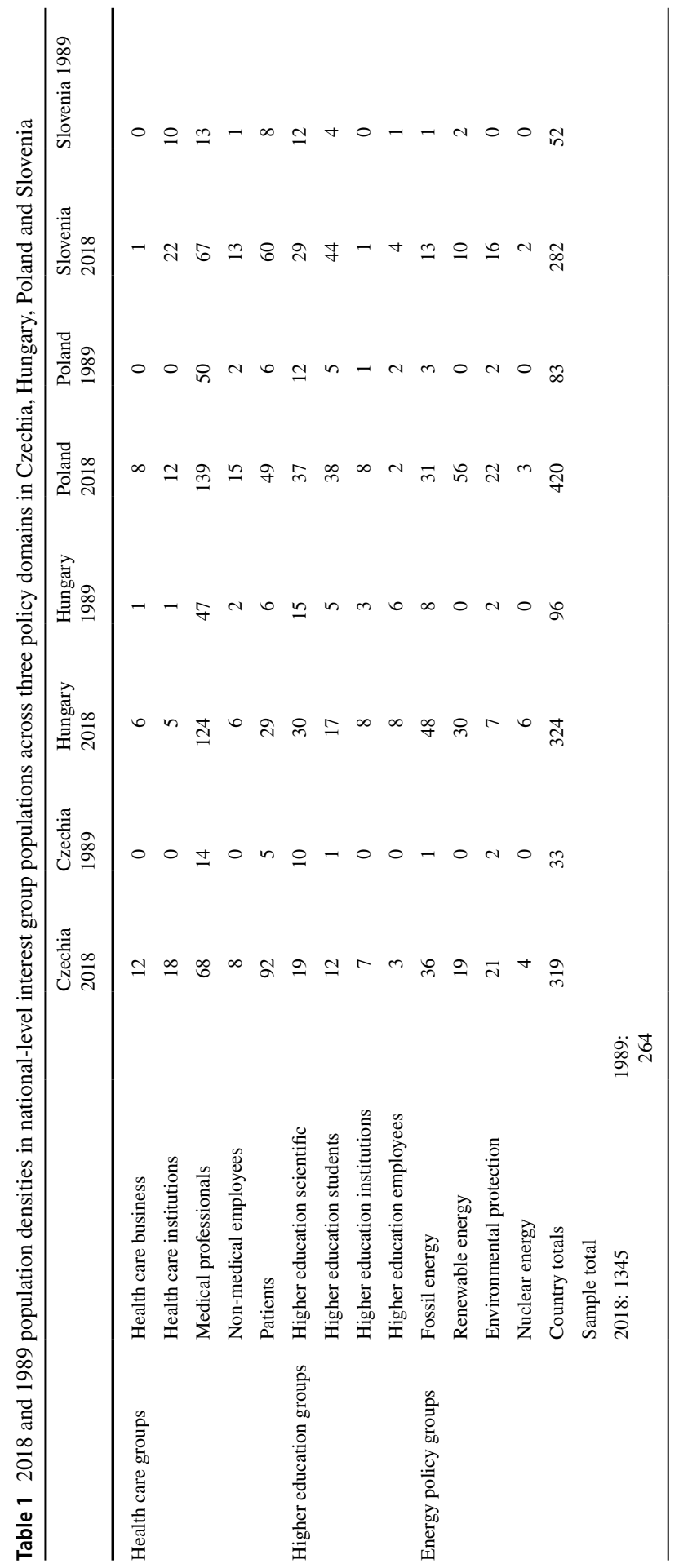

称 
countries, with Hungary having the most and Czechia the fewest national-level interest organisations in the three policy domains. However, the variance is much less pronounced across populations. The same populations contain the most organisations in 1989 across the four countries: medical professional groups, scientific higher education groups and patient organisations (in this order). The 2018 population densities show in general less variance. The almost three times bigger Hungarian 1989 organisational count compared to Czechia did not lead to significantly more organisations in these populations in Hungary 29 years later. The 2018 totals are roughly the same in these two, almost equally sized countries: 324 in Hungary and 319 in Czechia. Poland has almost four times the population size of Czechia and Hungary has in total only about 100 more organisations (420) in 2018 across the three policy domains. In Slovenia, with a population of only 2 million, we nevertheless counted almost the same number of organisations as in the five times larger Czechia and Hungary (282).

\section{Variables and statistical analysis}

Our dependent variable is the 2018 number of active Czech, Hungarian, Polish and Slovenian national-level interest groups across the above-mentioned 13 populations in three policy domains and four countries $(n=52$, see Table 1 for a detailed overview). Following Lowery and Gray (1995), the area term is conceptualised as the number of potential constituents. This is, however, problematic because of our dataset. Our populations contain both business and institutional, and sectional (scientific and professional as well as labor interests), and cause groups (environmental protection). As our sample only consists of four countries, we cannot test different models for business and institutional groups and the sectional and cause groups. Our aim was to find proxies for the size of latent constituencies that are measured on the same scale and at the same time are meaningful as a measurement of potential constituents for the organisations in a given population.

As a rule, to measure the latent constituency of organisations in populations, we relied on statistics on the logarithm of the employment in the sector per 100,000 inhabitants (see Table 2). However, employment was not in every case a fitting or a possible indicator of the size of constituency. For environmental policy groups, we took the logarithm of the number of premature deaths attributable to PM2.5, NO2 and O3 exposure per 100,000 inhabitants (EEA 2019). In case of health care patient groups, we used the logarithm of the number of standardised death rates (per 100,000 inhabitants) for treatable diseases/conditions among persons aged less than 75 in 2017 (Eurostat 2020f). For the higher education student and institutional groups, we used the logarithm of the number of tertiary education students per 100,000 inhabitants (Eurostat 2020e). The logged values offer a test of the density dependence of the area term (Berkhout et al. 2015; Lowery et al. 2010).

To test the resource hypothesis for the energy term, we rely on public expenditures as a proportion of GDP for the sector. In case of every population, we used the most detailed data sources available (Eurostat 2020d, 2021a, 2020b; Yearwood et al. 2020). Our second energy hypothesis targets issue certainty or the likelihood 


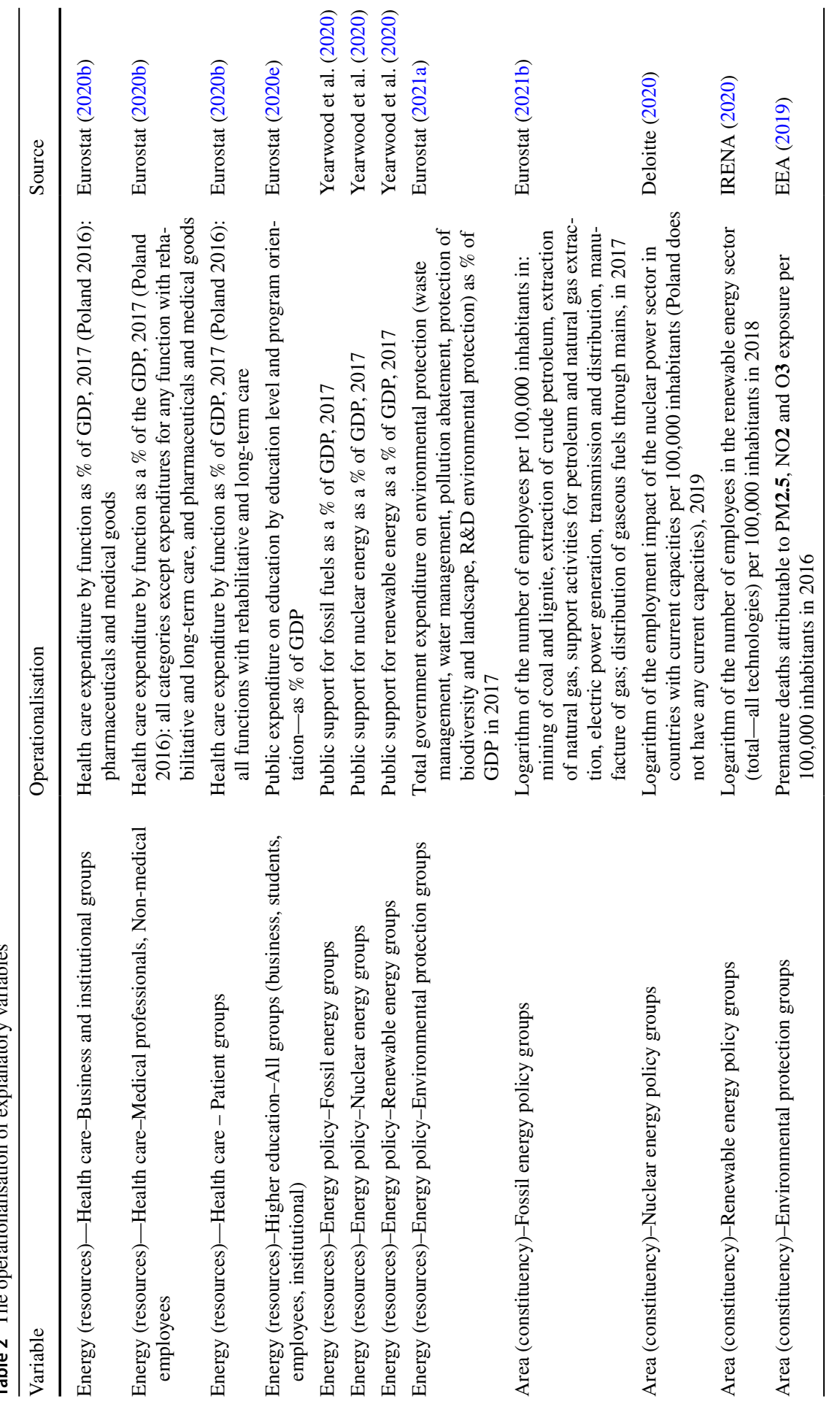




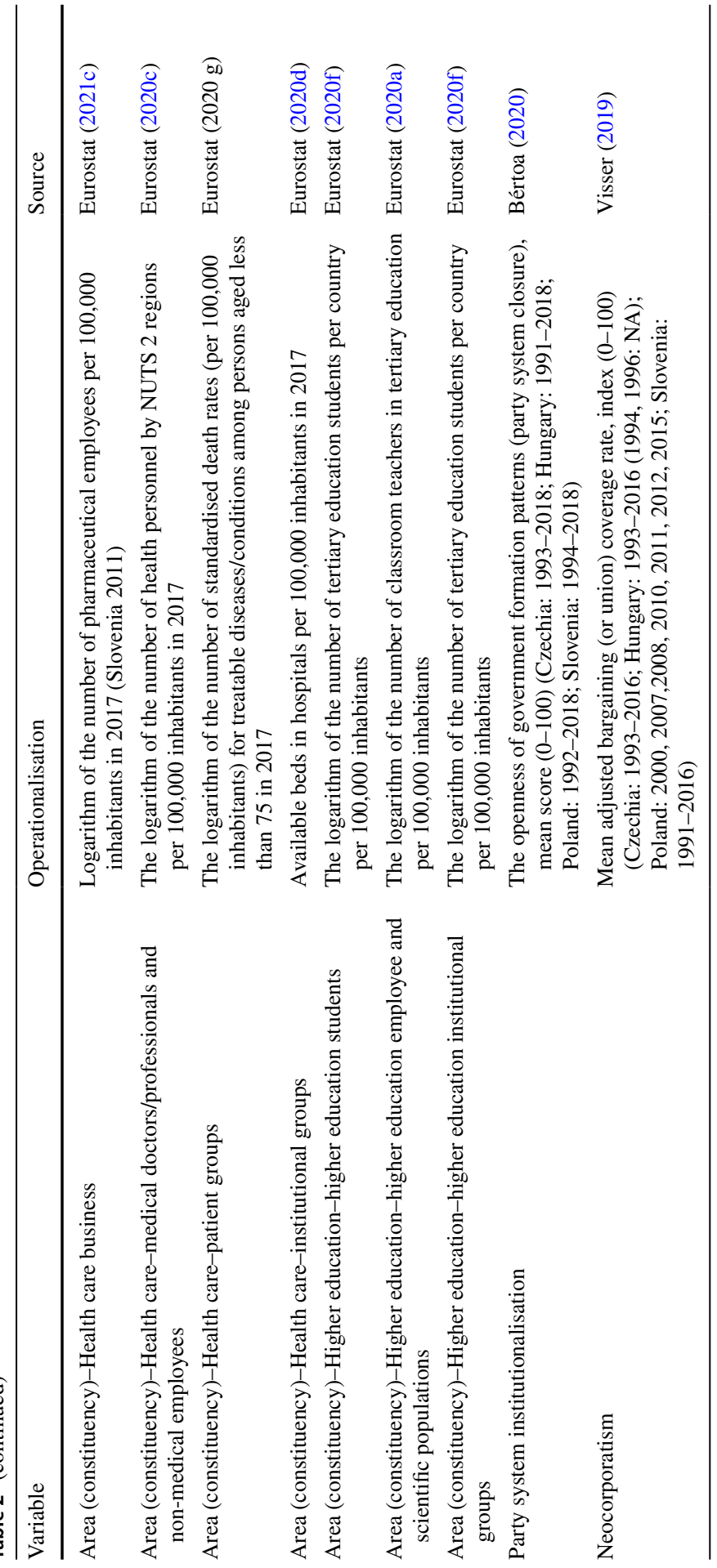


of policy change. To test this, in accordance with Lowery and Gray (1995), we also operationalised party competition. We apply a measurement of party system closure of Bértoa and Enyedi (2016). What makes it particularly useful for the purposes of this study is that the model concentrates on patterns of government formation. Its components are a) alternation of government (wholesale/none or partial, that is, all parties stay in government/all parties changed or are there some parties that stay in government as a part of a new coalition?), b) governing formulae (familiar or innovative, that is, the same party combinations govern or are there new, innovative coalitions?) and c) access to government (closed or open, that is are there parties that are permanently excluded from government?). Bértoa and Enyedi (2016) built a continuous scale of party system closure (0-100) based on this model and the averages for the period between 1990 and 2013. We use the average scores from the first year of available data to 2018 provided by Bértoa (2020) to test issue certainty. The higher the scores are, the more closed a party system is.

The party system closure scores confirm our assumptions on the differences between these party systems: In our sample, Hungary is the most closed, followed by Slovenia and the Czech Republic. Poland has the second-most open party system among the post-communist EU member states. However, in the averages between 1991 and 2018, the four party systems are not that different. Czechia, Slovenia and Hungary exhibit quite stable, relatively highly institutionalised party systems, and their average closure for the timeframes available is $91.01,88.5$ and 85.59 , respectively. Poland has the lowest average score of 82.5 . The Polish party system was among the most under-institutionalised in CEE in the early 1990s (with the lowest closure score of 62.25 in 1993), but became more institutionalised with time, reaching a score of 86.74 in 2018.

To test the hypothesised effect of corporatism, we apply the mean adjusted bargaining (or union) coverage rate $(0-100)$ by Visser (2019) available for our four countries for various periods between 1990 and 2018. The higher numbers signal stronger corporatism. This measure shows that Slovenia is by far the most corporatist country of the four. While coverage in Czechia and Hungary was relatively high in the early 1990s (at $44.7 \%$ and $45 \%$ in 1993, respectively), it quickly decreased to $30.4 \%$ and $22.8 \%$ in 2016, respectively. In Poland, it was $25 \%$ in 2000 (the first data point for the country in the dataset for this index) and collective bargaining coverage sank to a mere $17.2 \%$ in 2015. In Slovenia, coverage stood at $100 \%$ between 1991 and 2006 and decreased to $70.9 \%$ in 2016. Please refer to Table 2 for a detailed overview of the data and sources used for the explanatory variables.

To test the effect of pre-transition (1989) population densities on contemporary (2018) population densities, we apply two different models. First, we simply regress the 1989 densities on the 2018 densities, which is a linear assumption. For the years 1989 and 2018, population densities are positively and highly correlated, with a correlation coefficient of 0.83 . That is, we do not except any surprises, but a strong, positive linear effect on 2018 densities. However, this is a rather trivial assumption and as already noted in the theoretical framework section, it does not reveal anything about the effect on pre-transition densities on post-transition vital rates and densities. To test Hypothesis 2 on the curvilinear (density dependent) relationship between the 1989 population size and post-1989 
contemporary density, we need a different operationalisation of 1989 densities. Therefore, we also measure 1989 densities as a percentage of 2018 densities. This offers several advantages. First, this way, our measurement is independent from other environmental factors, that is, that those populations tended to have higher 1989 densities, which have well-organised and large latent constituencies and ample governmental resources regardless of the political and economic system of a country. Secondly, the 1989/2018 density ratio allows for the measurement of the effect of pre-transition organisations on the post-transition population vital rates. Even at equal 1989 and 2018 population densities, this operationalisation allows for independence between the two in case communist-era organisations were supplanted by post-transition organisations.

Figure 1 depicts the relationship between the number of organisations founded after the regime change and 1989 densities as a percentage of 2018 densities. We sorted the 1989/2018 densities proportion variable into quartiles as its distribution is very skewed. Figure 1 shows the mean number of post-transition organisations in 2018 populations across our 13 populations per the quartiles of the $1989 / 2018$ density proportions. The relationship is clearly nonlinear, at relatively low proportions, there are an increasing number of post-transition organisations in the 2018 populations, whereas at relatively high proportions, the number of post-transition organisations decreases. It is important to note that the mean number of post-transition organisations are still higher at higher proportion levels than at lower ones. This indicates that in most cases, high 1989/2018 density proportions also mean large 1989 densities and relatively high post-transition population growth, albeit at a declining rate.

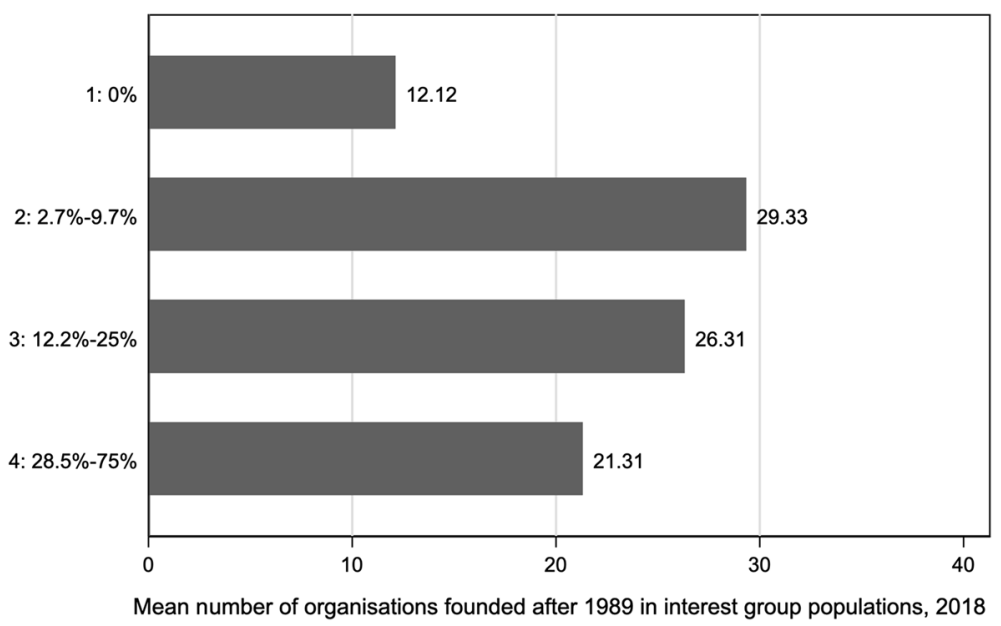

Fig. 1 Mean number of post-transition organisations per 1989/2018 density ratio quartiles in energy, higher education and healthcare group populations in 2018 - Czechia, Hungary, Poland, and Slovakia 


\section{Statistical analysis}

Our dependent variable is a count variable. The counts have integer values and are non-negative. Count data follow a Poisson distribution. A Poisson distribution is skewed-that is, the distribution of errors is not symmetric-and the variance increases with the mean - that is, the variance is not constant (Nownes 2004). One of the basic assumptions of a Poisson distribution is that the mean equals the variance. The violation of this assumption is problematic if the variance is higher than the mean, that is, in case of overdispersion. If there is evidence of overdispersion, a negative binomial regression is preferred to the Poisson regression (Hoffmann 2016). Our dependent variable is over-dispersed. Therefore, we estimated the models using negative binomial regression. We clustered the standard errors per country. Table 3 shows the estimated coefficients for the three negative binomial models along with their incidence rate ratios (IRRs).

Model 1 tests the area and the energy hypotheses, that is, the effect of the size of the latent constituency, governmental resources, issue certainty, controlled for the level of corporatism (as one of our countries in the sample-Slovenia-is very different from the others in this respect). The coefficient of the area term (constituency) is not statistically significant and is not in the expected direction. The model, however, confirms the resource hypothesis. The coefficient for resources is highly significant at $p<0.001$ and positive. A $1 \%$ increase in public expenditures (as \% of GDP) increases the expected number of organisations in a population by approximately $14 \%$. The coefficient for party system closure is also significant at $p<0.001$ and negative. A 1-point increase on the 100-point scale decreases the expected number of organisations by about $2 \%$. That is, closed and exclusive government formation patterns, and less frequent and more partial government change in a country affect population densities negatively. The coefficient of corporatism is highly significant at $p<0.001$, too, even if the effect proves to be rather modest. A 1-point increase on the 100-point scale of the mean adjusted bargaining coverage rate index decreases the expected number of organisations with $0.04 \%$. It appears that the level of neocorporatist interest intermediation affects organisational population densities somewhat negatively by restricting access to policy-makers and resources by elevating a number of bigger organisations within tripartite institutionalised social dialogue.

In Model 2, we added the 1989 density to the analysis. As the almost perfect and positive correlation predicted, the effect is significant at $p<0.001$ and positive even with all the other explanatory variables controlled for. However, as we already explained, we think this is a rather trivial finding. Moreover, it does not reveal anything about how exactly pre-transition population densities affect post-transition ones.

In Model 3, we added the 1989/2018 population density ratios instead and estimated the model with only the number of post-transition organisation per population as a dependent variable. That is, we excluded those organisations from the 2018 densities that were founded during Communism (or before the Communist takeover but were active all along). This way, our model allows for the measurement of the effect of pre-transition organisational densities on post-transition ones. If pre-transition organisations were supplanted by post-transition ones to a large enough degree, 


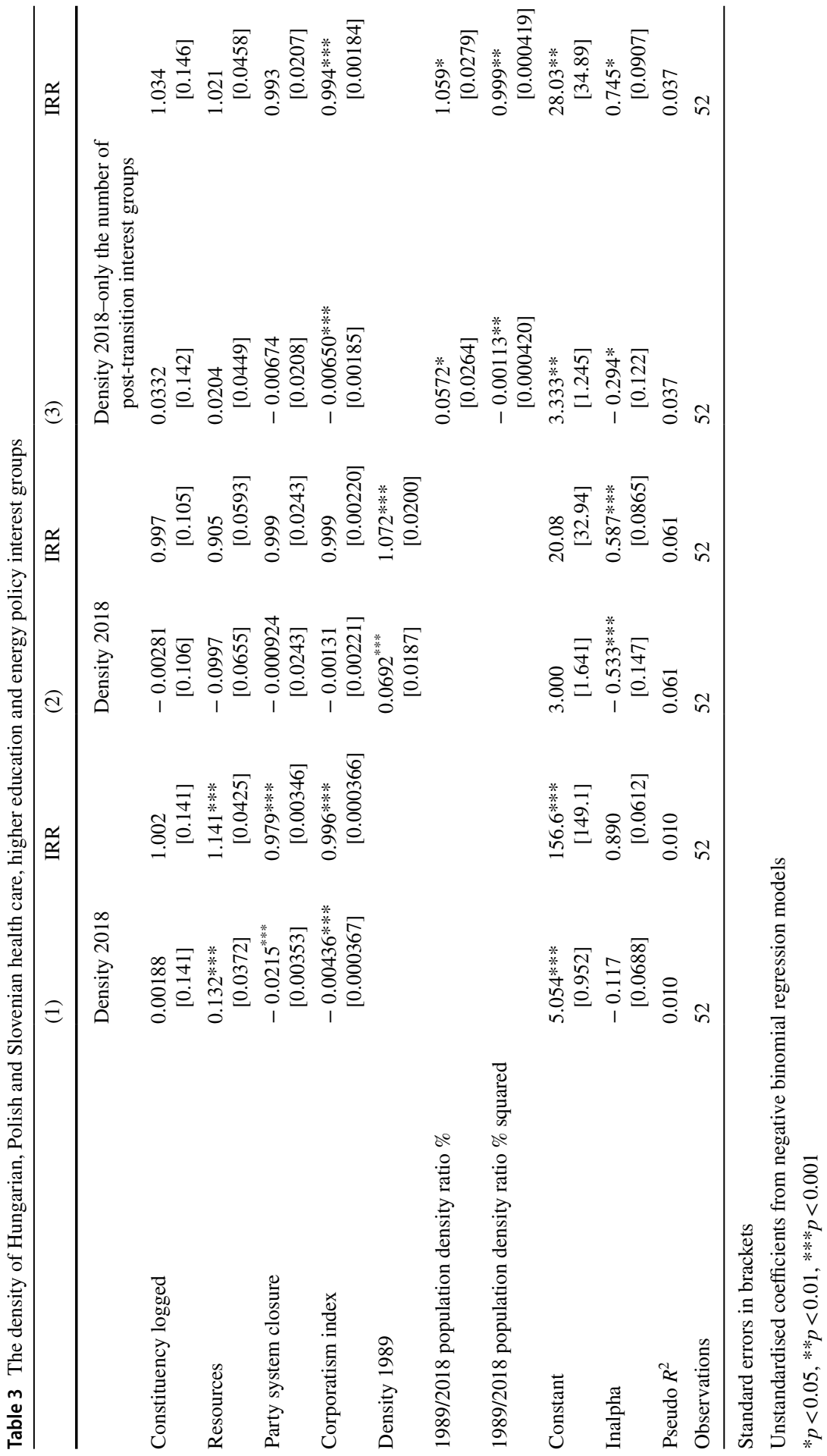


pre-transition densities should not exhibit a significant effect on post-transition ones. We also added the 1989/2018 densities ratio squared to the model to test whether the relationship is curvilinear. Model 3 supports hypothesis 2, the relationship between 1989 and 2018 is density dependent and curvilinear, both coefficients are statistically significant and in the expected direction: the 1989/2018 ratio coefficient is positive and the coefficient for its squared value is negative.

Figure 2 depicts the estimated predicted values of the number of post-transition organisations in 2018 at the different levels of the 1989/2018 densities ratio. Although our explanatory variable is a proportion, the dependent variable is a count variable. That is, from Fig. 2, it is possible to infer that until quite sizable pre-transition populations (in absolute terms, that is), there is a positive relationship between the size of pre-transition populations and the number of active post-transition organisations in 2018 populations. However, the graph also shows that after about $30-35 \% 1989 / 2018$ density ratios there is a decline in the expected number of posttransition organisations. The decline is so steep that at 40-50\% 1989/2018 density ratio the expected number of post-transition organisations in 2018 is roughly equal to the populations with a 10-15\% 1989/2018 density ratio. Of course, the former populations are larger in absolute terms as they contain more pre-transition organisations. The figure also shows that the distribution is really skewed, and the right tail is comprised of a few very small populations where a few pre-transition organisations seemed to have crowded out post-transition ones.

The findings indicate the longevity of communist-era organisations. Relatively high ratios signal populations where communist-era organisations hampered the foundation of new organisations and/or lowered their chances of survival. However, the positive effect until relatively high ratios also shows that the existence of a relatively sizable organisational population at the time of regime change could induce

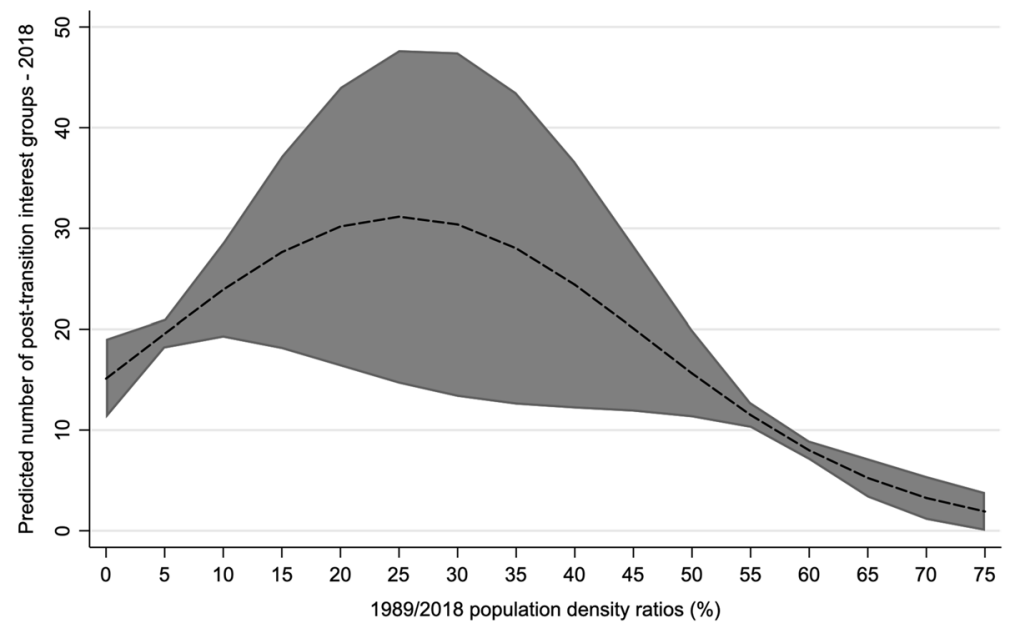

Fig. 2 Predictive margins for the number of post-transition interest groups in energy, higher education and healthcare group populations in 2018 - Czechia, Hungary, Poland, and Slovenia 
group formations. Although the other coefficients-with the exception of corporatism-are not significant, all of them are in the expected direction and the IRRs shows similar effects as in Model 1 . That is, we can tentatively conclude that governmental resources, issue certainty and neocorportatism moderate the effect of pretransition densities.

\section{Discussion and outlook}

Civil society and organised interests in CEE remain an understudied phenomenon. On the one hand, scholars have described the post-communist region as having a weak, underdeveloped civil society, heavily distorted by decades of communist authoritarian rule (Howard 2002). On the other hand, civil society movements (i.e., such as Solidarity in Poland, but also academic movements and to some extent environmental movements) contributed significantly and decisively to bringing down communism. Therefore, it is a highly intriguing question how organised interests have evolved in the post-communist phase, whether they advocated broader civic interests or more narrow, special interests through rent-seeking, and how their populations have evolved after 1989.

We analyzed the factors shaping interest group densities in the region by applying, for the first time, the energy-stability-area model of interest group population density on a sample of national-level Czech, Hungarian, Polish and Slovenian energy policy, higher education and health care interest organisation populations. We explored to what extent the size of constituencies (area), resources and the likelihood of policy change (energy), and different interest intermediation systems (the level of corporatism), as well as pre-existing civil society configurations, explain variation in the densities of different populations and subpopulations.

Our analysis showed that history matters and continues to reverberate three decades into the post-communist phase. The results of our analysis indicate the longevity and resilience of communist-era organisations after the political and economic (and in the case of Slovenia and Czechia, national) transition. Particularly, in smaller populations, the existence of a relatively sizable pre-transition population is associated with a smaller number of active organisations founded after transition even as late as 2018. However, in larger populations, the existence of a pre-transition population is associated with a higher number of post-transition organisations in contemporary populations. This indicates that other environmental factors moderate the effects of pre-transition population densities on post-transition organisational population development patterns. In other words, even in the face of the remarkable resilience of communist-era organisations, other factors such as resources and the likelihood for policy change matters.

Our analysis found support for the energy hypothesis: Resources and issue certainty affect post-communist population densities. More closed party systems tend to depress organisational formations. In other words, lively partisan competition and dynamic changes in coalition constellations boost interest group densities to some extent. When partisan constellations and competition become "stale," we do not observe an "escape" to civic organisations, as one might intuitively expect, 
rather the opposite, i.e., we observe a link between lively partisan dynamics and growing interest group densities. We found strong support for the importance of resources. Public expenditure levels affect population size significantly and profoundly. We also found evidence for the negative effect of corporatism on population densities. Although the effect is modest, it is highly significant and robust.

Future research should focus on the impact of other potentially relevant forms of disrupted stability on organisation population densities in the region. For example, the accession to the European Union, the financial crisis, as well as major (third-order) policy changes (Hall 1993) (e.g., new energy strategy) may also boost density rates. Researchers may also apply alternative operationalisations of partisan dynamics and competition, corporatism, as well as resources and constituencies in order to test whether our assumptions hold. For example, private expenditures for higher education and health care could also be taken into consideration. In other words, the fine-tuning of some existing indicators or experimenting with other indicators, particularly for the area term, may reveal that presentday factors bear greater significance than historical trajectories.

Funding Open Access funding enabled and organized by Projekt DEAL. This research was conducted as a part of the research project "The "Missing Link": Examining organised interests in post-communist policy making' of the University of Konstanz, Germany and the University of Opole, Poland funded by the Beethoven 2 Polish-German Funding Initiative of the Deutsche Forschungsgemeinschaft and the Narodowe Centrum Nauki. We sincerely thank both organisations for the generous funding.

\section{Declarations}

Conflict of interest On behalf of all authors, the corresponding author states that there is no conflict of interest.

Open Access This article is licensed under a Creative Commons Attribution 4.0 International License, which permits use, sharing, adaptation, distribution and reproduction in any medium or format, as long as you give appropriate credit to the original author(s) and the source, provide a link to the Creative Commons licence, and indicate if changes were made. The images or other third party material in this article are included in the article's Creative Commons licence, unless indicated otherwise in a credit line to the material. If material is not included in the article's Creative Commons licence and your intended use is not permitted by statutory regulation or exceeds the permitted use, you will need to obtain permission directly from the copyright holder. To view a copy of this licence, visit http://creativecommons.org/licen ses/by/4.0/.

\section{References}

Armingeon, K. 2011. Verbändesysteme: Strukturen und Funktionen der Interessenvermittlung. In Regierungssysteme in Mittel-und Osteuropa: Die neuen EU-Staaten im Vergleich, ed. F. Grotz and F. Müller-Rommel, 147-168. Wiesbaden: VS Verlag für Sozialwissenschaften.

Avdagic, S. 2005. State-labour relations in East Central Europe: Explaining variations in union effectiveness1. Socio-Economic Review 3 (1): 25-53.

Avdagic, S. 2006. One Path or Several? Understanding the Varied Development of Tripartism in New European Capitalisms. Köln: Max-Planck-Institut für Gesellschaftsforschung. 
Baum, J.A.C., and T.L. Amburgey. 2002. Organizational Ecology. In The Blackwell Companion to Organizations, ed. T.L. Amburgey, 304-326. Oxford: Blackwell Publishers Ltd.

Berkhout, J., B.J. Carroll, C. Braun, A.W. Chalmers, T. Destrooper, D. Lowery, S. Otjes, and A. Rasmussen. 2015. Interest organizations across economic sectors: Explaining interest group density in the European Union. Journal of European Public Policy 22 (4): 462-480.

Berkhout, J., M. Hanegraaff, and C. Braun. 2018. Is the EU different? Comparing the diversity of national and EU-level systems of interest organisations. In National Interest Organizations in the EU Multilevel System, ed. R. Esising, D. Rasch, and P. Rozbicka. London: Routledge.

Berkhout, J., and D. Lowery. 2011. Short-term volatility in the EU interest community. Journal of European Public Policy 18 (1): 1-16.

Bértoa, F.C. 2013. Post-communist politics: on the divergence (and/or convergence) of East and West. Government and Opposition 48 (3): 398-433.

Bértoa, F. C. (2020) 'The Database on WHO governs in Europe and beyond'. Available at: https:// whogoverns.eu/party-systems/party-system-institutionalization/ (Accessed: 22.10.2020).

Bértoa, F.C., and Z. Enyedi. 2016. Party system closure and openness: Conceptualization, operationalization and validation. Party Politics 22 (3): 265-277.

Bértoa, F.C., and P. Mair. 2012. Party system institutionalisation across time in post-communist Europe. In Party Government in the New Europe, ed. H. Keman and F. Müller-Rommel, 85-112. New York: Routledge.

Bevan, S. 2013. Continuing the collective action dilemma: the survival of voluntary associations in the United States. Political Research Quarterly 66 (3): 545-558.

Beyers, J., and B. Kerremans. 2007. Critical resource dependencies and the Europeanization of domestic interest groups. Journal of European Public Policy 14 (3): 460-481.

Biezen, I.V., and T. Poguntke. 2014. The decline of membership-based politics. Party Politics 20 (2): 205-216.

Binderkrantz, A.S., P.M. Christiansen, and H.H. Pedersen. 2015. Interest Group Access to the Bureaucracy, Parliament, and the Media. Governance 28 (1): 95-112.

Bohle, D., and B1. Greskovits. 2012. Capitalist diversity on Europe's periphery Cornell studies in political economy. Ithaca: Cornell University Press.

Bruszt, L, Campus N. F, Fidrmuc, J, and Roland, G. Civil society, institutional change and the politics of reform: The great transition. WIDER Working Paper Helsinki: The United Nations University World Institute for Development Economics Research (UNU-WIDER), 2010

Crowley, S., and D. Ost. 2001. Workers after workers' states : Labor and politics in postcommunist Eastern Europe. Lanham, MD: Rowman \& Littlefield Publishers.

Deloitte (2020) Economic and Social Impact Report Foratom, Bucharest: Deloitte Romania. Available at: https://www.foratom.org/press-release/investing-in-low-carbon-nuclear-generates-jobs-and-econo mic-growth-in-europe/.

Dobbins, M., R. Labanino, and B. Horváthová. 2021. Exploring Populations of Organized Interests in Post-Communist Central and Eastern Europe. In the "Missing Link": Exploring Organized Interests in Post-Communist Policy Making, ed. M. Dobbins and R. Riedel, 47-76. London: Routledge.

EEA (2019) Air Quality in Europe - 2019 report, Copenhagen: European Environment Agency10/2019). Available at: https://www.eea.europa.eu/publications/air-quality-in-europe-2019.

Ekiert, G., and J. Kubik. 1998. Contentious Politics in New Democracies: East Germany, Hungary, Poland, and Slovakia, 1989-93. World Politics 50 (4): 547-581.

Enyedi, Z., and F.C. Bértoa. 2018. Institutionalization and De-institutionalization in Post-communist Party Systems. East European Politics and Societies 32 (3): 422-450.

Eurostat (2020a) 'Classroom teachers and academic staff by education level, programme orientation, sex and age groups'. Available at: https://appsso.eurostat.ec.europa.eu/nui/show.do?dataset=educ_uoe_ perp01\&lang=en (Accessed: 03.11.2020).

Eurostat (2020b) 'Health care expenditure by function'. Available at: http://appsso.eurostat.ec.europa. eu/nui/show.do?query=BOOKMARK_DS-565686_QID_-30A07C28_UID_-3F171EB0\&layout= TIME,C,X,0;GEO,L,Y,0;UNIT,L,Z,0;ICHA11_HC,L,Z,1;INDICATORS,C,Z,2;\&zSelection=DS565686ICHA11_HC,TOT_HC;DS-565686INDICATORS,OBS_FLAG;DS-565686UNIT,EUR_ HAB;\&rankName1=ICHA11-HC_1_2_-1_2\&rankName2=UNIT_1_2_-1_2\&rankName3=INDIC ATORS_1_2_-1_2\&rankName4=TIME_1_0_0_0\&rankName5=GEO_1_2_0_1\&sortC=ASC_-1_ FIRST\&rStp $=\& \mathrm{cStp}=\& \mathrm{rDCh}=\& \mathrm{cDCh}=\& \mathrm{rDM}=$ true $\& \mathrm{cDM}=$ true $\&$ footnes $=$ false $\&$ empty $=$ false $\&$ wai $=$ false $\&$ time_mode $=$ NONE\&time_most_recent $=$ false $\&$ lang $=E N \& c f o=\% 23 \% 23 \% 23 \% 2 \mathrm{C} \%$ 23\%23\%23.\%23\%23\%23 (Accessed: 03.11.2020). 
Eurostat (2020c) 'Health personnel by NUTS 2 regions'. Available at: https://appsso.eurostat.ec.europa. eu/nui/show.do?dataset=hlth_rs_prsrg\&lang=en (Accessed: 10.08.2020).

Eurostat (2020d) 'Public expenditure on education by education level and programme orientation - as \% of GDP'. Available at: https://appsso.eurostat.ec.europa.eu/nui/show.do?dataset=educ_uoe_fine06\& lang=en (Accessed: 03.11.2020).

Eurostat (2020e) 'Students enrolled in tertiary education by education level, programme orientation, sex, type of institution and intensity of participation'. Available at: https://appsso.eurostat.ec.europa.eu/ nui/show.do?dataset=educ_uoe_enrt01\&lang=en (Accessed: 11.03.2020).

Eurostat (2020f) 'Treatable and preventable mortality of residents by cause and sex'. Available at: https:// appsso.eurostat.ec.europa.eu/nui/show.do?query=BOOKMARK_DS-500057_QID_-5998BF23_ UID_-3F171EB0\&layout=TIME,C,X,0;GEO,L,Y,0;MORTALIT,L,Z,0;SEX,L,Z,1;ICD10,L,Z,2; UNIT,L,Z,3;INDICATORS,C,Z,4;\&zSelection=DS-500057MORTALIT,TRT;DS-500057INDI CATORS,OBS_FLAG;DS-500057UNIT,RT;DS-500057SEX,T;DS-500057ICD10,TOTAL;\& rankName1=ICD10_1_2_-1_2\&rankName2=UNIT_1_2_-1_2\&rankName3=MORTALIT_1_ 2_-1_2\&rankName4=INDICATORS_1_2_-1_2\&rankName5=SEX_1_2_-1_2\&rankName6= 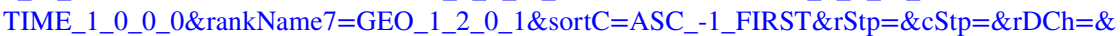 $\mathrm{cDCh}=\& \mathrm{rDM}=$ true $\& \mathrm{cDM}=$ true $\&$ footnes $=$ false $\&$ empty $=$ false $\&$ wai $=$ false $\&$ time_mode $=$ NONE $\&$ time_most_recent=false \&lang=EN\&cfo=\%23\%23\%23\%2C\%23\%23\%23.\%23\%23\%23 (Accessed 20.08.2020).

Eurostat (2021a) 'General government expenditure by function (COFOG)'. Available at: https://ec. europa.eu/eurostat/databrowser/view/gov_10a_exp/default/table?lang=en (Accessed 08.04.2021).

Eurostat (2021b) 'Industry by employment size class (NACE Rev. 2, B-E)'. Available at: https://appsso. eurostat.ec.europa.eu/nui/show.do?dataset=sbs_sc_ind_r2\&lang=en (Accessed 21.04.2021).

Eurostat (2021c) 'SBS data by NUTS 2 regions and NACE Rev. 2 '. Available at: https://appsso.eurostat. ec.europa.eu/nui/show.do?dataset=sbs_r_nuts06_r2\&lang=en (Accessed 22.04.2021).

Fink-Hafner, D. 'Interest Organizations in the Policy-making Process', in Fink Hafner, D. and Robbins, J.R. (eds.) Making a new nation : the formation of Slovenia. Aldershot, England ; Brookfield, Vt., USA: Dartmouth, pp. 114-134, 1997

Fink-Hafner, D. 2011. Interest Representation and Post-Communist Parliaments over Two Decades. The Journal of Legislative Studies 17 (2): 215-233.

Fraussen, B., J. Beyers, and T. Donas. 2015. The Expanding Core and Varying Degrees of Insiderness: Institutionalised Interest Group Access to Advisory Councils. Political Studies 63 (3): 569-588.

Fraussen, B., and D. Halpin. 2016. Assessing the Composition and Diversity of the Australian Interest Group System. Australian Journal of Public Administration 75 (4): 476-491.

Fraussen, B., and D.R. Halpin. 2018. Political parties and interest organizations at the crossroads: Perspectives on the transformation of political organizations. Political Studies Review 16 (1): 25-37.

Gallai, S., Z. Döme, B. Molnár, and J. Reich. 2015. What makes them successful? Influential interest groups in Hungary (1990-2014). Europe-Asia Studies 67 (9): 1469-1486.

Gehlbach, S., and E.J. Malesky. 2010. The contribution of veto players to economic reform. The Journal of Politics 72 (4): 957-975.

Gray, V., and D. Lowery. 1995. The demography of interest organization communities: institutions, associations, and membership groups. American Politics Quarterly 23 (1): 3-32.

Gray, V., and D. Lowery. 1996a. Environmental limits on the diversity of state interest organization systems: A population ecology interpretation. Political Research Quarterly 49 (1): 103-118.

Gray, V., and D. Lowery. 1996b. A niche theory of interest representation. The Journal of Politics 58 (1): 91-111.

Gray, V., and D. Lowery. 1996c. The Population Ecology of Interest Representation. Lobbying Communities in the American States. Ann Arbor: University of Michigan Press.

Greskovits, B. 1998. The political economy of protest and patience: East European and Latin American transformations compared. Budapest: Central European University Press.

Hall, P.A. 1993. Policy paradigms, social learning, and the state: The case of economic policymaking in Britain. Comparative Politics 25 (3): 275-296.

Halpin, D.R., and H.F. Thomas III. 2012. Evaluating the breadth of policy engagement by organized interests. Public Administration 90 (3): 582-599.

Hanley, S. 2013. The development of pensioners' Interest Organisations in Central and Eastern Europe: A Comparison of the Czech and Slovene Cases. Europe-Asia Studies 65 (1): 45-74.

Hannan, M.T., and G.R. Carroll. 1992. Dynamics of Organizational Populations. Oxford: Oxford University Press. 
Hannan, M.T., and J. Freeman. 1977. The Population ecology of organizations. American Journal of Sociology 82 (5): 929-964.

Hannan, M.T., and J. Freeman. 1989. Organizational ecology. Cambridge, Mass.: Harvard University Press.

Hellman, J.S. 1998. Winners take all: The politics of partial reform in postcommunist transitions. World Politics 50 (2): 203-234.

Hoffmann, J.P. 2016. Regression Models for Categorical Dependent Variables Using Stata. Oakland: University of California Press.

Howard, M.M. 2002. The weakness of postcommunist civil society. Journal of Democracy 13 (1): $157-169$.

Iankova, E.A. 2002. Eastern European capitalism in the making. New York: Cambridge University Press.

Ibenskas, R., and A. Sikk. 2017. Patterns of party change in Central and Eastern Europe, 1990-2015. Party Politics 23 (1): 43-54.

IRENA (2020) 'Renewable Energy Employment by Country'. Available at: https://www.irena.org/ Statistics/View-Data-by-Topic/Benefits/Renewable-Energy-Employment-by-Country (Accessed 21.04.2020).

Jahn, D. 2016. Changing of the guard: Trends in corporatist arrangements in 42 highly industrialized societies from 1960 to 2010. Socio-Economic Review 14 (1): 47-71.

Klüver, H. 2015. Interest groups in the German bundestag: Exploring the issue linkage between citizens and interest groups. German Politics 24 (2): 137-153.

Kopecký, P., and C. Mudde. 2003. Rethinking civil society. Democratization 10 (3): 1-14.

Korkut, U., A. de Ruyter, M. Maganaris, and D. Bailey. 2017. What next for unions in Central and Eastern Europe? Invisibility, departure and the transformation of industrial relations. European Journal of Industrial Relations 23 (1): 65-80.

Krzywdzinski, M. 2008. Arbeits- und Sozialpolitik in Polen. Interessenvermittlung und politischer Tausch in einem umkämpften Politikfeld. Wiesbaden: VS Verlag für Sozialwissenschaften.

Labanino, R., M. Dobbins, S. Czarnecki, and A. Železnik. 2020. Explaining the Formation Rates of PostCommunist Interest Organizations: Density Dependence and Political Opportunity Structure. East European Politics and Societies: and Cultures. https://doi.org/10.1177/0888325420950809.

Labanino, R., M. Dobbins, and R. Riedel. 2021. There is no tabula rasa - The effect of communist rule on organizational formations in pre-transition interest group populations. In The "Missing Link": Exploring Organized Interests in Post-Communist Policy Making, ed. M. Dobbins and Rafał Riedel, 25-46. London: Routledge.

Lizzi, R., and A. Pritoni. 2017. The size and shape of the Italian interest system between the 1980s and the present day. Italian Political Science Review/rivista Italiana Di Scienza Politica 47 (3): 291-312.

Lowery, D., and V. Gray. 1995. The population ecology of gucci gulch, or the natural regulation of interest group numbers in the American States. American Journal of Political Science 39 (1): 1-29.

Lowery, D., V. Gray, and J. Monogan. 2008. The construction of interest communities: Distinguishing bottom-up and top-down models. The Journal of Politics 70 (4): 1160-1176.

Lowery, D., S. Otjes, S. Gherghina, A. Van Witteloostuijn, G. Peli, and H. Brasher. 2010. Unpacking LogM: Toward a More General Theory of Party System Density. American Journal of Political Science 54 (4): 921-935.

Mair, P. 2013. Ruling the Void. The Hollowing of Western Democracy. London: Verso.

Meyer, D.S., and D.R. Imig. 1993. Political opportunity and the rise and decline of interest group sectors. The Social Science Journal 30 (3): 253-270.

Meyer, D.S., and D.C. Minkoff. 2004. Conceptualizing political opportunity. Social Forces 82 (4): 1457-1492.

Minkoff, D., S. Aisenbrey, and J. Agnone. 2014. Organizational diversity in the U.S. advocacy sector. Social Problems 55 (4): 525-548.

Novak, M., and D. Fink-Hafner. 2019. Slovenia: Interest group developments in a postsocialist-liberal democracy. Journal of Public Affairs 19 (2): 1-13.

Nownes, A.J. 2004. The population ecology of interest group formation: mobilizing for gay and lesbian rights in the United States, 1950-98. British Journal of Political Science 34 (1): 49-67.

Nownes, A.J., and D. Lipinski. 2005. The Population ecology of interest group death: Gay and lesbian rights interest groups in the United States, 1945-98. British Journal of Political Science 35 (2): 303-319.

Offe, C. 1991. Capitalism by democratic design? Democratic theory facing the triple transition in East Central Europe. Social Research 58 (4): 865-892. 
Olson, M. 1965. The logic of collective action; public goods and the theory of groups Harvard economic studies. Cambridge Mass: Harvard University Press.

Olson, M. 1982. The rise and decline of nations : Economic growth, stagflation, and social rigidities. New Haven: Yale University Press.

Ost, D. 2005. The defeat of Solidarity : Anger and politics in postcommunist Europe. Ithaca, N.Y.: Cornell University Press.

Pleines, H. 2004. Social partners and captors. The role of non-state actors in Central and Eastern Europe. Romanian Journal of Political Science 4 (1): 51-65.

Putnam, R.D., R. Leonardi, and R. Nanetti. 1994. Making democracy work : Civic traditions in modern Italy. Princeton, N.J.: Princeton University Press.

Rozbicka, P, and Kamiński, P. (2021) 'Have They Already Emerged? Mapping the Population of National Interest Organisations in Post-Communist Poland', Europe-Asia Studies, pp. 1-20.

Sebestény, I. 2017. A civil szektor demográfiája a civil szervezetek névjegyzékének retrospektív feldolgozása alapján. Civil Szemle 14 (1): 7-33.

Stinchcombe, A.L. 1965. Social Structure and Organizations. In Handbook of Organizations, ed. J.G. March, 142-193. Chicago: Rand McNally \& Company.

Szabó, I. 2013. Between polarization and statism-effects of the crisis on collective bargaining processes and outcomes in Hungary. Transfer European Review of Labour and Research 19 (2): 205-215.

Tóth, A. 2012. The New Hungarian Labour Code-Background, Conflicts, Compromises. Budapest: Friedrich Ebert Stiftung.

Vachudova, M.A. 2005. Europe undivided: democracy, leverage, and integration after communism. Oxford New York: Oxford University Press.

Visser, J. 'Institutional Characteristics of Trade Unions, Wage Setting, State Intervention and Social Pacts, 2010, 1960-2017 (ICTWSS)' (Version 6.0). Available at: https://www.ictwss.org/downloads (Accessed: 03.11.2020).

Wonka, A., F.R. Baumgartner, C. Mahoney, and J. Berkhout. 2010. Measuring the size and scope of the EU interest group population. European Union Politics 11 (3): 463-476.

Yearwood, J, Torres, P, Badouard, T, Moreira de Oliveira, D, and Altmann, M. Study on energy costs, taxes and the impact of government interventions on investments-Country subsidy factsheets, Luxembourg: European CommissionENER/2018-A4/2018-471, 2020 Available at: https://ec.europa.eu/ energy/studies_main/final_studies/study-energy-costs-taxes-and-impact-government-interventionsinvestments_en.

Publisher's Note Springer Nature remains neutral with regard to jurisdictional claims in published maps and institutional affiliations. 